Kong. Res. J. 3(1) : 65-66, 2016

ISSN 2349-2694

Kongunadu Arts and Science College, Coimbatore.

\title{
ANTIBACTERIAL ACTIVITY OF METHANOLIC RHIZOME EXTRACT OF ALPINIA CALCARATA ROSC. (ZINGIBERACEAE)
}

\author{
Arumugasamy, K*., R. Nantha Kumar, H. Abdul Kaffoor, and A. Shalimol \\ PG and Research Department of Botany, Kongunadu Arts and Science College (Autonomous), Coimbatore. \\ *E.mail: arumugasamy_kasc@yahoo.co.in
}

\begin{abstract}
The methanolic rhizome extract of A. calcarata was evaluated for its antibacterial activities against five bacterial strains Pseudomonas aeuroginosa, Proteus vulgaris, Salmonella paratyphi, Bacillus thurungiensis and Staphylococcus faccealis. The extract has inhibited all the tested bacterial species with different manner at various concentration. However the higher level zone of inhibition in $400(\mathrm{mg} / \mathrm{ml})$ is significant against all the above said bacterial strains of these Salmonella paratyphi. Based on the present study it can be conculuded that the plant rhizome possess potent anti bacterial activity.
\end{abstract}

Keywords: Alpinia calcarata, antibacterial, Salmonella paratyphi.

\section{INTRODUCTION}

Natural products, such as plants extract, either as pure compounds or as standardized extracts, provide unlimited opportunities for new drug discoveries because of the unmatched availability of chemical diversity (Cosa et al., 2006). The use of herbal medicines in Asia represents a long history of human interactions with the environment. Plants used for traditional medicine contain a wide range of substances that can be used to treat chronic as well as infectious diseases (Duraipandiyan et al., 2006). Due to the development of adverse effects and microbial resistance to the chemically synthesized drugs, mankind turned to ethnopharmacognosy. They found literally thousands of phytochemicals from plants as safe and broadly effective alternatives with less adverse effect.

Alpinia calcarata Rosc. (Zingiberaceae) is an important medicinal plant among the seven species of Alpinia that occur in Bangladesh, India, Myanmar, Indonesia, Thailand. It is a perennial herb with non tuberous pungent root stock. Its rhizomes showed antinociceptive activities (Arambewela et al., 2004).

\section{MATERIALS AND METHODS}

Freshly collected rhizome of A. calcarata was cut in to small pieces and shade dried. All the dried parts were pulverized by mechanical grinder to get the powder through 100 mesh sieve and stored in a air tight container. Required quantity of powder was weighed and transferred to a conical flask. The powder was treated with various solvents like petroleum ether, methanol, chloroform, ethanol and aqueous. This process was repeated for a week and the extract was filtered through Whatman No.1 filter paper. The filtrate was collected and evaporated to dryness. The concentrated residue was used for various phytochemical and biological studies.

\subsection{Tested organisms}

The bacterial strains Pseudomonas aeuroginosa, Proteus vulgaris, Salmonella paratyphi, Bacillus thurungiensis, Staphylococcus faccealis employed in this study were purchased from Department of microbiology, Bharathidasan University, Trichirappali. All these cultures were maintained on nutrient and potato dextrose agar plates at $4^{\circ} \mathrm{C}$ in lab.

\subsection{Antibacterial assay}

Anti bacterial activity of various concentration of $A$. calcarata rhizome was determined by the disc diffusion method (Bauer et al., 1966). All petridishes were plated with nutrient agar prepared according to the manufacturer's manual given below.

\section{Chemical composition of nutrient agar medium for bacterial culture}

$\begin{array}{lll}\text { S.No. } & \text { Composition } & \text { Quantity }(g) \\ \text { 1. } & \text { Peptone } & 5.0 \\ \text { 2. } & \text { Beef extract } & 3.0 \\ \text { 3. } & \text { Sodium chloride } & 5.0 \\ \text { 4. } & \text { Agar } & 15.0 \\ \text { 5. } & \text { Distilled water } & 1000 \mathrm{ml} \\ 6 . & \text { pH } & 7.0\end{array}$

Sterile liquid nutrient agar medium ( $\mathrm{pH} 7.4 \pm 2$ ) was poured $(15-20 \mathrm{ml})$ into each sterile petriplate. The test organisms were inoculated with the help of a sterile cotton swap soaked in respective bacterial culture grown in peptone broth. The disc containing plant extract was placed on the solidified agar plate in such a way that there is no overlapping of zone of inhibition. Chloramphenicol antibiotic disc $(10 \mathrm{mg})$ 
was used as standard. Plates were kept at room temperature for half an hour for the diffusion of the sample into agar media. The organisms inoculated in the petridishes were incubated in thermostat at $37^{\circ} \mathrm{C}$ for 24 hrs. The zone of inhibition produced by plant extract on different organisms were measured and recorded by using zone reader. Antibacterial activity was evaluated by measuring the zone of inhibition against the test organisms. Each assay was conducted in triplicate.

\section{RESULTS}

Antibacterial activity of A.calcarata (Zingiberaceae) in methanol extract was carried out against selected negative bacterial strains Staphylococcus aureus, Pseudomonas aeroginosa, Proteus vulgaris, Salmonella paratyphi and positive strain Bacillus subtilis and these are compared with reference antibiotic, Ampicillin. Generally, methanol extract with the concentration of $400(\mathrm{mg} / \mathrm{ml})$ showed a significant zone of inhibition against all the above said bacterial strains. of these Salmonella paratyphi,has showed highest degree of inhibition followed by, Staphylococcus aureus, Bacillus subtilis, Pseudomonas aeroginosa,and Proteus vulgaris. Methanol extract with the concentrations of 300 $(\mathrm{mg} / \mathrm{ml})$ and $200(\mathrm{mg} / \mathrm{ml})$ showed a moderate activity against all the bacteria.Thus the methanolic extract of $A$. calcarata in significant level shows antibacterial activity and it could be used for controlling bacterial diseases.

\section{DISCUSSION}

The crude extracts from rhizome of A.calcarata in methanolic solvent were subjected to antimicrobial screening against selected Gram positive and Gram negative bacteria. All the extracts showed varying degree of inhibitory potential against all the tested bacteria. Acetone and chloroform extracts of leaf had higher inhibitory action against Salmonella typhi and Streptococcus subtilis respectively. Acetone extracts of stem showed maximum inhibitory action against $S$. typhi and benzene extracts of stem had moderate inhibitory action against Escherichia coli (Viji and Murugaesan, 2010). Ripa et al. (2010) have explained Nephelium longan has significant antimicrobial activity. Chloroform extracts of leaf and stem showed excellent activity with the average zone of inhibition of $13-21 \mathrm{~mm}$ among the tested bacteria. The ethyl acetate crude extracts showed good activity against the growth of Sarcina lutea, Vibrio mimicus, Salmonella typhi, E.coli and Staphylococcus aureus. Susceptibility of various microbes to the methonalic extract of the plant sample in our study suggest the scope for developing antimicrobial natural herbal drugs on the it is concluded that the promising antimicrobial properties of the plant extract could be exploited in herbal preparation against bacterial infection justifying their use in traditional medicine.

Table 1. Antibacterial activity of various concentration extract of $\boldsymbol{A}$. calcarata

\begin{tabular}{|c|c|c|c|c|c|c|}
\hline \multirow{3}{*}{ S.No. } & \multirow{3}{*}{ Microorganism } & \multicolumn{5}{|c|}{ Zone of inhibition(mm) } \\
\hline & & \multicolumn{4}{|c|}{ Various concentration of extracts used $(\mathrm{mg} / \mathrm{ml})$} & \multirow{2}{*}{$\frac{\text { Ampicillin }}{10 \mathrm{mg} / \mathrm{ml}}$} \\
\hline & & $100 \mathrm{mg} / \mathrm{ml}$ & $200 \mathrm{mg} / \mathrm{ml}$ & $300 \mathrm{mg} / \mathrm{ml}$ & $400 \mathrm{mg} / \mathrm{ml}$ & \\
\hline 1. & Pseudomonas aeuroginosa & - & - & 6 & 6 & 22 \\
\hline 2. & Proteus vulgaris & - & - & - & - & 29 \\
\hline 3. & Salmonella paratyphi & 7 & 8 & 8 & 9 & 30 \\
\hline 4. & Bacillus thurungiensis & - & - & - & 7 & 15 \\
\hline 5. & Staphylococcus faccealis & - & - & - & 8 & 16 \\
\hline
\end{tabular}

\section{REFERENCES}

Cosa, P., A.J. Vlietinck, D.V. Berghe and L. Maes. 2006. Anti-infective potential of natural products: How to develop a stronger in vitro „proof-of-conceptJ. Ethnopharmacol., 106: 290-302.

Bauer, A.W., Kirby, W.M.M., Sherris, J.C. and M. Turck, 1966.Antibiotic Susceptibility Testing by a Standardized Single Disk Method.Am. J. Clin. Pathol. 45: 493-496.

Viji, M, and S. Murugesan. 2010. Phytochemical analysis and antibacterial activity of medicinal plant Cardiospermumhalicabum Linn. J. Phytol., 2: 68-77.
Ripa, F.A., Haque, M and I.J Bulbul. 2010. In vitro Antibacterial, Cytotoxic and Antioxidant Activities of Plant Nephelium longan. Pak. J. Biol. Sci., 13(1): 22-27.

Duraipandiyan V, Ayyanar M, Ignacimuthu S (2006). Antimicrobial activity of some ethnomedicinal plants used by Paliyar tribe from Tamil Nadu, India. BMC Complement Altern Med., 17;6:35.

Arambewela LSR, Arawwawala LDAM, Ratnasooriya WD (2004). Antinociceptive activities of aqueous and ethanolic extracts of Alpinia calcarata rhizomes in rats. J. Ethnopharmacol., 95(2-3): 311-316. 